\title{
Hormone replacement therapy, cancer, controversies, and women's health: historical, epidemiological, biological, clinical, and advocacy perspectives
}

\author{
Nancy Krieger, Ilana Löwy, Robert Aronowitz, Judyann Bigby, Kay Dickersin, Elizabeth Garner, \\ Jean-Paul Gaudillière, Carolina Hinestrosa, Ruth Hubbard, Paula A Johnson, Stacey A Missmer, \\ Judy Norsigian, Cynthia Pearson, Charles E Rosenberg, Lynn Rosenberg, Barbara G Rosenkrantz, \\ Barbara Seaman, Carlos Sonnenschein, Ana M Soto, Joe Thornton, George Weisz
}

J Epidemiol Community Health 2005;59:740-748. doi: 10.1136/jech.2005.033316

Routine acceptance of use of hormone replacement therapy (HRT) was shattered in 2002 when results of the largest HRT randomised clinical trial, the women's health initiative, indicated that long term use of oestrogen plus progestin HRT not only was associated with increased risk of cancer but, contrary to expectations, did not decrease, and may have increased, risk of cardiovascular disease. In June 2004 a group of historians, epidemiologists, biologists, clinicians, and women's health advocates met to discuss the scientific and social context of and response to these findings. It was found that understanding the evolving and contending knowledge on hormones and health requires: (1) considering its societal context, including the impact of the pharmaceutical industry, the biomedical emphasis on individualised risk and preventive medicine, and the gendering of hormones; and (2) asking why, for four decades, since the mid-1960s, were millions of women prescribed powerful pharmacological agents already demonstrated, three decades earlier, to be carcinogenic? Answering this question requires engaging with core issues of accountability, complexity, fear of mortality, and the conduct of socially responsible science.

See end of article for authors' affiliations

Correspondence to: Professor N Krieger, Department of Society, Human Development and Health, Harvard School of Public Health, Kresge 717, 677 Huntington Avenue, Boston, MA 02130, USA; nkrieger@hsph.harvard. edu

Accepted for publication 27 May 2005 experience, laboratory research, and observational epidemiological studies, for using HRT to stave off ill effects of aging and to prevent cardiovascular disease. ${ }^{6-11}$

Immediate consequences of the alarming new HRT findings included a dramatic decrease in prescriptions and marketing of HRT in the USA (for example, by 53\% for oestrogen plus progestin, by $18 \%$ for oestrogen alone $)^{12-15}$ and other countries. ${ }^{16}$ Moreover, within both the clinical and epidemiological literature, sharp debates swiftly broke out-and continue-regarding the reasons for the different findings of the prior studies and the new investigations. ${ }^{3}{ }^{17-24}$

Contending explanations for the discrepancies, whose testing in future epidemiological research will probably yield new insights into the harms and benefits of HRT for women's health, include: (1) confounding in observational studies unmasked by use of randomised clinical trials (for example, women prescribed HRT tend to be healthier and more affluent, and thus at lower risk of cardiovascular disease, resulting in spurious associations between HRT and reduced risk of cardiovascular disease); (2) selection by indication (for example, some physicians, aware of concerns about cardiovascular effects of contraceptives, may have been less likely to prescribe HRT to women at higher risk for cardiovascular disease); (3) use of the wrong study population in the clinical trials (older women past menopause (WHI mean age $=63.3$ years $^{1}$ ), thereby precluding assessment of HRT use only during the menopausal transition on subsequent disease risk); (4) use of different formulations and doses of HRT in diverse studies; and (e) methodological problems in detecting acute increases in risk (for example, of a heart attack) in observational cohort studies designed to collect data only once every two years. $^{3}{ }^{4}$ 17-24

The current debates over HRT would suggest that serious concerns about use of HRT are a novel phenomenon. They also imply that current scientific awareness of possible risks associated with HRT is attributable chiefly to scientific progress, with new studies debunking old ideas.

Abbreviations: HRT, hormone replacement therapy; WHI, women's health initiative; HERS, heart and estrogen/progestin replacement study 
Such a rendering of the scientific discourse, however, is grossly inaccurate. In fact, biological, clinical, and epidemiological evidence emphasising risks and discounting purported benefits associated with what is now conventionally termed HRT has been published for well over a half century (table 1). ${ }^{25-40}$ At issue, then, is not simply the "advance" of scientific knowledge-but also why decades of repeated warnings about dangers of manipulating and prescribing hormones to "treat" menopause were ignored and not translated into health policies.

To begin to address the question of why the WHI and HERS results were perceived and depicted as "shocking,",5 and to consider the implications for research and practice regarding women's health and use of sex hormones as pharmacological agents, in June 2004 a group of historians, epidemiologists, biologists, clinicians, and women's health advocates gathered for a two day interdisciplinary and comparative exploratory symposium on hormones, women, and cancer risk: professionals and activists facing "miracle molecules" held at the Radcliffe Institute for Advanced Studies in Cambridge, MA (USA). The initial idea for the symposium was proposed by Dr Ilana Löwy, and it was coorganised by Professor Nancy Krieger. Each group presented and invited discussion on its analysis of key issues regarding HRT use (table 2). Perhaps the outstanding lesson, delineated in table 2 , is the necessity of framing contemporary scientific research and policy in historical, social, economic, and political context, so as to illuminate the oft concealed technical, administrative, economic, and political decisions and values that shape scientific inquiry and its impact on population health.

\section{DISCIPLINARY INSIGHTS: HRT AND HISTORY, WOMEN'S HEALTH ADVOCATES, EPIDEMIOLOGY, BIOLOGY, AND CLINICAL MEDICINE \\ History}

Reminding participants that use of hormones as pharmacological agents has never been without controversy, the historians presented a picture of three waves of debate about oestrogen use during the 20th century. The first occurred in the 1930s, once laboratory techniques succeeded in making oestrogens available as a manufactured drug. $25283241-43$ During this period, biochemists and endocrinologists conducted animal experiments that provided evidence of the carcinogenicity of sex hormones; for clinicians, these studies translated to debates about the correct dose to be given, as hormones were viewed as "natural" and thus not intrinsically harmful. ${ }^{44}$ The second wave occurred in the 1960s and 1970s, triggered by new health concerns about oral contraceptives, oestrogen only HRT and risk of endometrial cancer, plus the carcinogenicity of tobacco and environmental pollutants. ${ }^{44}{ }^{45}$ The third wave is currently underway, and involves both concerns about the carcinogenicity of HRT and disputes over its presumed long term health benefits, including reducing risk of cardiovascular disease. ${ }^{4}{ }^{17-24} 34-4044$

Noting changing participants and data over time, the historians described how the first wave principally involved laboratory scientists and clinical specialists in endocrinology and gynaecology. ${ }^{28} 4244$ Their disputes were largely restricted to scientific and clinical journals, did not include either patients or the popular press, and were based on studies conducted among small samples of women. By contrast, in the second and third wave, women as patients and health advocates, along with regulatory agencies and the popular press, engaged as active participants. ${ }^{45-51}$ Additional medical subspecialties (cardiology, gerontology, oncology) also joined in; industry exerted a far greater influence on both pharmacological research and public discourse (for example, Ayerst, a leading pharmaceutical company, underwrote Wilson's 1966 best selling pro-HRT book Feminine Forever $^{52}{ }^{53}$ ); and more data were available from both hospital based studies and cancer registries. ${ }^{54}$ The net effect was to create a far more visible debate, with more participants and higher stakes.

Historical analysis additionally shows that the prominence and views of different sectors in the debate have varied within and across countries, within and over time. During the second and third waves, for example, French feminists and gynaecologists, who in France were principally women, plus women in the UK, were more positive toward hormone use than their US counterparts, with both patients and physicians supporting use of HRT to relieve symptoms; ${ }^{.55} 56$ the French physicians also valued evidence of physiological mechanisms more than results of large scale clinical trials that minimised attention to individual variations in response to HRT. ${ }^{56}$ Industry interest in plus government regulation of prescription of sex hormones has also intensified over time, with concern typically focused more on preventing harm than establishing benefits (especially long term benefits not detectable without lengthy follow up $)^{457}$;8, efforts to couch arguments for HRT in terms of chronic disease "risk reduction" is a comparatively recent development. Thus, while there is no one single debate about use of HRT, similar themes are evident in all of the controversies, spanning

Table 1 Short chronology of the history of sex hormones, production, and use of oestrogen for menopause, and cancer

\begin{tabular}{|c|c|}
\hline Decade & Key issues \\
\hline $1930 \mathrm{~s}$ & $\begin{array}{l}\text { The commercial production and sale of hormones as drug }{ }^{42}{ }^{43} \text { was accompanied by debates on the potential danger of induction of } \\
\text { malignancies. }{ }^{25-28}\end{array}$ \\
\hline $1940 s-1950 s$ & $\begin{array}{l}\text { Doubts on the safety of menopausal hormones. }{ }^{29-32} \text { Premarin is nevertheless a commercial success, as women increasingly began to use } \\
\text { menopausal hormones. }{ }^{146}{ }_{147}\end{array}$ \\
\hline $1960 \mathrm{~s}$ & $\begin{array}{l}\text { Changes in women's status and life expectancy encourage menopausal therapy: publication of Feminine forever }(1966)^{52} \text { : HRT is presented as a } \\
\text { therapy that allows women to free themselves from the malediction of oestrogen loss, and to conserve femininity. }{ }^{6-10}\end{array}$ \\
\hline 1970 s & $\begin{array}{l}\text { The rise of women's movement and women's health movement. }{ }^{66} 1381391_{141-144} \text { Rise of feminist criticism of the pill and of HRT, }{ }^{4566} 67131 \text { in context of } \\
\text { broader concerns about dangers of "hormone therapy" (including DES). }{ }^{148-150} \text { The description of increase in the incidence of endometrial cancer } \\
\text { in women who used menopausal oestrogen (1975) }\end{array}$ \\
\hline $1980 \mathrm{~s}$ & $\begin{array}{l}\text { The widespread introduction of progestin-oestrogen treatment for women with an intact uterus. HRT is increasingly presented as a preventive drug: } \\
\text { from "young and sexy forever," the emphasis shifts to "healthy forever." }{ }^{\prime \prime 9} 5356 \text { From early } 1980 \mathrm{~s} \text { on, a steady increase in use of HRT (as measured } \\
\text { in number of prescriptions and sale of drugs), despite the persistence of critical voices. }{ }^{35-37} \text { At the end of 1980s, HRT consumption exceeded the pre- } \\
1975 \text { volume. }\end{array}$ \\
\hline 1990s & $\begin{array}{l}\text { The steady increase in HRT uptake continues. This treatment is strongly promoted by most of doctors, and sustained, especially in the USA, by the } \\
\text { ethos of individualised preventive medicine. } 104080126-128 \text { It continues, nevertheless, to be questioned by scientists, feminist scholars, and advocates, } \\
\text { in their overlapping permutations. } \text {. }^{39} 4040-5063646678153154 \mathrm{WHI} \text { - the first large scale randomised prospective clinical trial of menopausal } \\
\text { hormones - starts, partly as an answer to feminist criticism of HRT. }\end{array}$ \\
\hline 2000 s & $\begin{array}{l}2002 \text { - HERS results on cardiovascular disease are surprising. }{ }^{2} \text { Early interruption of WHI, after the finding of an excess of cancers and } \\
\text { cardiovascular incidents in the experimental branch.' In 2002-2003, a sharp decrease in HRT prescriptions in English speaking countries. }{ }^{2-15}\end{array}$ \\
\hline
\end{tabular}


Table 2 Key issues relevant to debates over use of HRT from different disciplinary perspectives: history, women's health advocates, epidemiology, biology, and clinical medicine

\begin{tabular}{|c|c|}
\hline Discipline & Key issues \\
\hline History & $\begin{array}{l}\text { (1) Disciplinary boundaries affecting understanding and awareness of risk. } \\
\text { (2) Definition, production, and use of pharmaceutical substances. } \\
\text { (3) Definition and practice of medical subspecialties. } \\
\text { (4) Comparative histories of medical practice. } \\
\text { (5) Impact of previous and contemporary medical and public health debates on HRT use. }\end{array}$ \\
\hline Women's health advocates & $\begin{array}{l}\text { (1) "Expose the abuse, critique the science, light the fire": critical role of women's health advocates. } \\
\text { (2) Political clout of pharmaceutical industry and manipulation of "consumer" fears and desires as "choice." } \\
\text { (3) Contrast between "curative" and "risk management" treatments. } \\
\text { (4) Role of medical-industrial complex in manufacturing and marketing drugs for profit. } \\
\text { (5) Debates on drugs rarely linked to debates over structure of health care system. }\end{array}$ \\
\hline Epidemiology & $\begin{array}{l}\text { (1) Inadequate use of appropriate study design (RCT), over-reliance on observational data, disregard for RCTs not favourable to } \\
\text { HRT, and poor interpretation of epidemiological studies. } \\
\text { (2) Disregard of socially patterned confounding, vis a vis who does and does not take HRT. } \\
\text { (3) Disregard for risk in relation to age (risk of breast cancer greater than coronary heart disease among women in their } 40 \text { s and } \\
50 \text { s), and discounting of adverse risk of breast cancer relative to risk reduction for cardiovascular disease. } \\
\text { (4) Disregard for distinctions between absolute and relative risk. } \\
\text { (5) Impact of pharmaceutical industry on epidemiological research, including emphasis on alleged benefits over risks and revised } \\
\text { view of "acceptable risks" for healthy populations. }\end{array}$ \\
\hline Biology & $\begin{array}{l}\text { (1) Hormones by definition are global signallers in the body, such that "side effects" of hormonal therapies are inevitable. } \\
\text { (2) Steroid hormones affect more than the reproductive system and are involved in cell growth and differentiation, as well as } \\
\text { immunity, metabolism, and behaviour. } \\
\text { (3) Endogenous and exogenous hormones, including xenoestrogens, are typically studied in systems that show only a small } \\
\text { portion of their biological activity. } \\
\text { (4) Ignorance vastly exceeds knowledge about the full range of biological functions of endogenous hormones and exogenous } \\
\text { hormone-like agents. } \\
\text { (5) The complexity of biological systems precludes accurate quantitative "risk assessment" and is not compatible with non- } \\
\text { precautionary "command and control" approaches to regulating and licensing safe levels of individual chemicals. }\end{array}$ \\
\hline Clinical medicine & $\begin{array}{l}\text { (1) Among the wealthier countries in which pharmaceutical companies have their principal markets, the pharmaceutical industry } \\
\text { increasingly underwrites conferences and research, plus offsets journal costs through extensive advertising. } \\
\text { (2) In these same countries, the "best selling" drugs currently are "risk reducing" drugs, consonant with an increasing trend to } \\
\text { focus on eliminating individual risk. } \\
\text { (3) Limited time, low reimbursement for counselling (cognitive services), and defensive medicine shape medical practice, } \\
\text { increasing medical conformity and encouraging physicians to prescribe "risk reducing" drugs. } \\
\text { (4) Clinical guidelines encourage physicians to prescribe treatments even if there is not conclusive evidence that drugs are the best } \\
\text { way to approach risk reduction. } \\
\text { (5) Until recently, physicians in the USA were encouraged at least to counsel women about the use of HRT as a standard of care } \\
\text { for women during and after menopause, but have now been discouraged from routinely prescribing it. }\end{array}$ \\
\hline
\end{tabular}

nearly 70 years and involving production, prescription, marketing, use, regulation, and availability of data to test claims of harms and benefits of pharmacological products.

\section{Women's health advocates}

The women's health advocates in turn highlighted the role of advocacy in uncovering hidden risks of pharmaceuticals routinely marketed for and to women, especially in relation to reproductive health. ${ }^{45}{ }^{50}$ Recounting the founding of the National Women's Health Network in 1975 and its origins in the civil disobedience by women's health activists at the 1970 US Senate hearing on the birth control pill (for which no women patients had been asked to testify), ${ }^{59}{ }^{60}$ the activists described how central tenets of their work have included informed consent, full disclosure, and the demand that women-as the intended users of HRT and other drugs affecting women's reproductive systems-have an active role in shaping the development, testing, and regulation of these drugs.

In their view, the experience with HRT underscored the political clout of the pharmaceutical industry and its manipulation of "consumer" fears and desires as "choice." These companies had privileged access to women through their physicians, and to the physicians and researchers through funding of conferences, training programmes, and research. The industry also drew on ethnographic techniques to identify key opinion leaders who could shape physicians' and patients' attitudes to-and receptivity towards-the pharmacological use of sex hormones (pages $115-55^{57}$ ). Together, the pharmaceutical companies, physicians, and researchers effectively colluded to promote the view that menopause is a "deficiency disease," and that women needed long term treatment with HRT to prevent illness, loss of sexuality, and ugly aging. ${ }^{52} 53556162$ Use of drugs shifted from being "curative" to being a tool of "risk management," requiring long term administration to an ever-expandingand hence profitable-market of aging users. ${ }^{43-65}$

The initial demand of the women's health movementthat women have control over and become knowledgeable about their own bodies - thus was diluted and subverted into a tightly medically supervised activity of testing for disease or pre-disease and "choosing" from an array of drugs and tests controlled by physicians and the pharmaceutical industry. The drugs themselves likewise took on a life of their own, as products to be marketed, such that when HRT use declined because of fear of endometrial cancer, new reasons needed to be found for their prescription. Thus, low bone density ("osteopenia"), previously just one of many risk factors, was reframed as the very definition of osteoporosis; this condition, only detectable with new technologies, provided a new rationale for long term prescription of HRT to menopausal women (pages $145-76^{50}$ ).

While highlighting the importance of unmasking risks of various specific drugs intended to regulate women's reproductive health, the advocates also emphasised the need to consider the broader question of drug uptake in the context of the marketing imperatives of pharmaceutical companies, drug regulation, and the overall structure of the health care industry. ${ }^{45} 66{ }^{67}$ In this process, the activists have engaged repeatedly with regulatory agencies; in the USA, for example, activists strongly supported the 1977 decision of the Food and Drug Administration (FDA) to make mandatory patient 
packet inserts for oestrogens and likewise were instrumental in challenging the widely sanctioned use of HRT for unproven indications, for example, protection from cardiovascular disease. $^{455066}$ By questioning the economic and political agendas behind the growing medicalisation of women's reproductive lives and health, as exemplified by the saga of HRT, the women's health advocates hoped to re-ignite a focus on the fundamental question of the social, political, and economic conditions needed for all women to be able to enjoy reproductive and sexual autonomy, live healthy lives, age with dignity, and die with minimal suffering.

\section{Epidemiology}

Recognising the centrality of epidemiological evidence to arguments in favour of and against HRT use, the epidemiologists focused on debates over and changes in the epidemiological data on links between hormones, cancer, and cardiovascular disease. ${ }^{17-24}{ }^{33-40}$ At issue was not only the quality and interpretation of epidemiological studies, but also beliefs about the role of sex hormones in women's and men's health.

Thus, starting in the late 1920s and early 1930s, UK and US epidemiological studies began to implicate endogenous sex hormones in breast cancer, by detecting links between risk of breast cancer and women's reproductive history (for example, age at menarche, nulliparity, age at first pregnancy, number of children, etc). ${ }^{68-70}$ In the mid-20th century, concerns about the rise in coronary heart disease mortality, occurring at an earlier age among men than women, led to the presumption (bolstered by laboratory evidence ${ }^{10}$ ) that endogenous sex hormones were key to differences in women's and men's cardiovascular health ${ }^{71} 72$ and thus that use of oestrogens might reduce risk of cardiovascular disease. $^{10}$ Simultaneously, the increasing proportion of women living longer after menopause (because of declines in deaths from childhood infectious disease and from maternal mortality) raised new questions about women's healthy aging. ${ }^{73}{ }^{74}$

Starting in the mid-1970s, some epidemiologists began questioning HRT's presumed cardiovascular benefits. During the early 1970s, the oestrogen treatment arms of the coronary drug project, a clinical trial of HRT among men only for cardiovascular disease prevention, started in the mid-1960s, were discontinued because of increased adverse cardiovascular outcomes among the men receiving oestrogens. ${ }^{34} 75$ Concomitantly, epidemiological research linked rising use of HRT to rising rates of endometrial cancer. ${ }^{76} 77$ By the mid1980s, some epidemiologists were noting that women who took HRTs were, from the outset, generally healthier-and more affluent-than women who did not. ${ }^{1178}$ These cautionary findings, however, were dwarfed by the proliferation of studies favourable to HRT, while RCTs providing contrary evidence were downplayed and even disregarded. ${ }^{79}$ Also ignored were epidemiological data showing that the absolute risk of breast cancer was higher than that of cardiovascular disease among younger women, particularly among the great majority who are non-smokers, such that women were in effect being asked to increase their short term and not inconsiderable risk of cancer with the hope of decreasing their long term risk of cardiovascular disease. ${ }^{80}$

In summarising the conflicting epidemiological evidence, the epidemiologists emphasised the importance of studying women's health in context. Had differences in women's and men's cardiovascular health not been reduced principally to a question of sex hormones, alternative hypotheses for potential interventions to prevent cardiovascular disease and to explain the changing epidemiological profiles of both cancer and cardiovascular disease might have received more attention. ${ }^{71}$ Moreover, had the social patterning of HRT use been taken seriously, the probable confounding giving rise to HRT's association with reduced risk of cardiovascular disease almost surely would have garnered more critical attention. ${ }^{11} 19-24397881$ Critical review of the epidemiological evidence thus requires careful analysis of the underlying theories of disease distribution used, the hypothesis considered, who is and is not included in each study, potential biases, and how the data are analysed and interpreted. ${ }^{17-24} 33-40$ 81-88

\section{Biology}

Central to the biologists' presentations was the complexity of endocrine systems. Steroid hormones serve as virtually global signalling molecules, circulating throughout the organism and exerting many long range impacts on the wide variety of tissues that express the hormone receptors that mediate their effects ${ }^{89}{ }^{90}$ As a result, so called "sex hormones" have myriad effects not only on reproduction but also cell proliferation, differentiation, and development in many tissues, as well as on metabolism, immunity, and cognition..$^{43}{ }^{89-91}$ Conversely, exogenous substances, whether "natural" (for example, oestrogenic flavanoids in soy) or manufactured (for example, pesticides such as DDT, plus various chemicals in plastics, plasticisers, antioxidants, and detergents), can have hormonal effects because of their interactions with hormone receptors. ${ }^{92-95}$ Research has identified a very large number of synthetic substances with endocrine disrupting properties, including xenoestrogens, which have oestrogenic effects. ${ }^{89}$ 92-98 Hormonal pharmaceuticals are thus but only one class of manufactured substances that can affect the endocrine systems of humans and other species. ${ }^{97-106}$ Only a small fraction of the roughly 100000 chemicals in commerce have been tested for endocrine activity, and some 2000 new chemicals are brought to the market each year. ${ }^{107}$

The biological consequences of exposure to endogenous and exogenous hormones depend on both the dose and timing and can therefore be difficult to predict. ${ }^{90}{ }^{108}$ For example, in utero exposure to oestrogens causes lifelong structural and functional changes in genital tract organs and mammary glands, and can lead to a 20-fold to 25-fold increase in the proportion of oestrogen receptor positive cells in the uterine epithelial lining. ${ }^{109}$ For women, research shows that mammary gland tissues are especially vulnerable to effects of sex steroids during not only prenatal development but also puberty and the perimenopause. ${ }^{70}{ }^{110-112}$ Concern about the impact of HRT on carcinogenesis thus needs to be coupled with investigation of the impact of exposure to xenoestrogens across the life course, starting with conception-if not before, given possible effects on germ cells and gametes. ${ }^{90} 108109$

Importantly, difficult as it may be to measure the exact timing and dose of HRT exposure, recording and quantifying exposure to myriad hormonally active substances-in the food supply, air, water, and consumer products-is even more challenging. Relevant exposures may extend back to in utero and, making long term tracking complicated, only some xenohormones persist within the body, whereas others are quickly metabolised and excreted. ${ }^{92-95}{ }^{113-115}$ The complexity of human endocrinology-which is characterised by feedback and feedforward dynamics, pleiotropy, plasticity, and combinatorial effects-defies simple "cause and effect" predictions. ${ }^{116}$ Consequently, for the foreseeable future, efforts to minimise chemical induced health and environmental risks will be based on incomplete knowledge. Strategies that require proof or fine scale predictions of specific links between individual chemicals and health risks before restrictive action can be taken are unlikely to be effective prevention policies. ${ }^{116-118}$ An alternative approach, known as the precautionary principle, posits that chemicals and 
processes that may plausibly result in irreversible and/or widespread damage to health and ecosystems should be presumed hazardous until proved otherwise and should be avoided entirely if safer, more ecologically sustainable alternatives are available or can be developed. ${ }^{94}{ }^{99}$ 116-120

\section{Clinical medicine}

Physicians have enormous power to affect their patients' lives and in turn powerful forces influence physicians. As the clinicians recounted, among these are the ethical imperative to "first do no harm" and to provide the best care possible, plus their socialisation in medical school to be authorities on human biology and behaviour. Also critical, especially in the USA (given its lack of national health insurance) are financial incentives that emphasise payment for acute care in hospital settings, reward physicians for seeing more patients in a limited time, and devalue training and reimbursement for preventive care, ${ }^{121}$ combined with the threat of malpractice. Moreover, despite efforts to prohibit drug company giveaways and open access to physicians in the clinical setting, "risk reducing" drugs have become "best sellers" via such strategies as the pharmaceutical industry's sponsorship of physician education and direct to consumer marketing. ${ }^{57} 58122$ Importantly, the pool of potentially "at risk" persons to whom preventive drugs can be sold far exceeds the number of persons clinically diagnosed with disease, and prescribing pills is more profitable than promoting behavioural and social changes that could potentially reduce risk. ${ }^{123}$

In the case of HRT, these different influences converged to the point where prescribing HRT became the standard of care, as a form of "preventive medicine" ${ }^{\prime 24}$ with many physicians believing it improved women's wellbeing and quality of life, ${ }^{378}$ especially given longer life expectancy and greater risk of disabling disease after menopause. Despite concerns about possible bias in the observational studies toward healthy women and reports of increased breast cancer risk among women taking HRT, physicians nevertheless accepted the argument women should take HRT because of the much higher prevalence of cardiovascular disease compared with breast cancer. Conflicting reports, recommendations, and clinical guidelines about the use of HRT, ${ }^{125-128}$ coupled with women's requests for HRT, limited time for office visits, and limited reimbursement for patient counselling likewise contributed to the rise of HRT prescribing. With patients increasingly recast as "consumers," and physicians as "gatekeepers" to medications, for physicians to express scepticism about HRT was tantamount to denying their patients "choice" - a substantive as well as ideological breach of mainstream market mentalities in which health care is a commodity, not a social good.

After the results of the WHI were reported physicians quickly changed their prescribing habits related to HRT. ${ }^{12-15}$ Prescriptions plummeted and many women found

\section{What is already known on this topic}

- Recent controversies over the harms and benefits of hormone replacement therapy (HRT) have shown that long term use of the combined oestrogen plus progestin HRT not only is associated with risk of breast and ovarian cancer but, contrary to expectations, does not decrease and in fact may increase risk of cardiovascular disease.

- Conventional wisdom suggests that serious concerns about HRT are a novel phenomenon.

\section{What does this article add?}

- Suggesting conventional wisdom, however, errs, our paper draws on insights gained from interdisciplinary dialogue and debated generated by an exploratory seminar including historians, epidemiologists, biologists, clinicians, and women's health advocates, focused on a symposium. Hormones, women, and cancer risk: professionals and activists facing "miracle molecules" - and argues the question we must confront is: why, for four decades, since the mid-1960s, were millions of women prescribed powerful pharmacological agents already shown, three decades earlier, to be carcinogenic?

- Key themes raised regarding the shaping of scientific knowledge and clinical practice included: the impact of the pharmaceutical industry, the biomedical emphasis on individualised risk and preventive medicine, and the gendering of hormones.

themselves having to ask for prescriptions to treat extremely uncomfortable hot flashes or because they did not feel well without the drug treatment. The overwhelming evidence for increased breast cancer risk for women who remained taking the combined oestrogen plus progestin HRT for five or more years and the increased risk of stroke, acute coronary syndromes, and thromboembolic disease persuaded many physicians to recommend that their patients stop HRT. Also influencing physicians was the potential threat of medical malpractice if they continued to prescribe the drugs. The dramatic change in prescribing practices, coupled with the lack of time to spend with patients to have informed discussions about the benefit and harms of taking HRT and continued uncertainty about best practices to manage menopausal symptoms, ${ }^{129}$ left many women, who ultimately have the right to make their own benefit-harm decisions, wondering what to do. ${ }^{130}$

\section{REFRAMING THE HRT DEBATES: THE BENEFITS OF AN INTERDISCIPLINARY DIALOGUE}

Yet, despite the complexities highlighted throughout the interdisciplinary dialogue and debate at our seminar, most mainstream discussion of HRT present the recent revelations that HRT may harm rather than benefit women's health as a case of science "doing it right," meaning that new evidence overturned prior ill founded and untested beliefs, one instance among many in the progress of human knowledge. This superficial reading, however, masks five important elements that together show the scientific enterprise is not simply a neutral or self correcting endeavour.

Missing element number 1: the invisible industrialist As evident from each disciplinary perspective, throughout the 20th century, industry has played a critical part in the development and interpretation of scientific knowledge about the effects of hormones on health: endogenous hormones, exogenous hormones manufactured as pharmaceutical products, and most recently, endocrine disruptors, as described above. Its influence has been achieved not only through the direct funding and control of research, but also by funding the training and continuing education of scientists and physicians alike. These latter practices, however, are rarely if ever regulated by governments, which instead chiefly have been concerned with regulating marketing of pharmaceutical products and providing funds for basic research critical for industrial science. Together, these 
Policy implications

- Understanding evolving and contending knowledge on hormones, HRT, and health requires engaging not only with the science of-and scientific debates over-the harms and benefits of HRT but also its societal context.

- Far from a simple tale of scientific progress, the science of HRT requires engaging with core issues of accountability, complexity, fear of mortality, and the conduct of socially responsible science.

priorities have fuelled the rise of a subsidiary biomedical industry involving the conduct of clinical trials and clinical epidemiology.

\section{Missing element number 2: regulatory agencies and} public compared with private interests

Governmental agencies, such as the US FDA, the UK Committee for the Safety of Medicines (CSM) and the Medicines and Healthcare Products Regulatory Agency (MHRA) in the UK, and, recently, France's Agence francaise de sécurité sanitaire des produits de santé (Afssaps, founded in 1998), have played a key-and at times contradictorypart in the HRT story. The 1977 FDA requirement for a patient package for oestrogens, including HRT, which the US Pharmaceutical Manufacturers Association fought in the courts (and lost), was probably one of the reasons for the decline in HRT sales in the late 1970s and early 1980s. ${ }^{4131}$ FDA staff likewise played an important part in events leading to conduct of the WHI, and since publication of the WHI results 2002, the FDA, along with the CSM, MHRA, and Afssaps have been actively disseminating information about health impacts of hormone use to both health professionals and users of health services. ${ }^{132-134}$ Yet, until recently, these same regulatory agencies effectively permitted the ever widening "off label" use of HRT among women, for example, for untested claims regarding prevention of cardiovascular disease, in part because of the influence of pharmaceutical companies. ${ }^{4505758}$ To understand the complex and contradictory actions of the regulatory agencies, more transparency about the role of private interests affecting the public interest is required.

\section{Missing element number 3: beliefs regarding individual compared with collective risk}

Contemporary biomedicine focuses on the management of individual risk, construed as consequence of individual "lifestyles" combined with genetic predisposition, while effectively ignoring societal risks that shape changing population profiles of disease and social inequalities in health. ${ }^{82^{83}{ }^{135-139}}$ In the case of HRT, the emphasis on individual risk contributed to research that ignored women's social and ecological context, thereby hindering rigorous analysis of socially patterned confounding and the possible impact of endocrine disruptors.

\section{Missing element number 4: the irresistible growth of individualised "preventive medicine"}

A focus on individual risk, combined with a commercial imperative-for industry and physicians alike-to promote pharmacological products that could be used by broad sectors of the population for long periods of time, in turn has led to mass marketing of "lifestyle" drugs. The widespread desire for-or at least acceptance of-such drugs reflects the commercial success of tapping into powerful fears of death plus hopes for "immortality." The underlying belief is that if people "do the right things" — avoid risky behaviours, eat
Recommendations for future scientific research

and clinical practice, building on an

interdisciplinary analysis of the lessons from the HRT saga

- Require greater transparency regarding funding of scientific and medical training, research, and publications, especially to expose potential conflicts of interest arising when funders stand to gain economically from the issues, activities, and products they are either: (a) underwriting, or (b) attempting to obfuscate.

- Require the protocols and results of all drug trials, regardless of study phase or findings, to be registered in publicly accessibly registries that can be freely and easily searched.

- Apply the precautionary principle to "preventive medicine" and "risk reducing" drugs, plus challenge the growing consensus, fuelled by the pharmaceutical industry, that it is "acceptable" to increase disease risk in currently healthy persons by prescribing drugs intended to prevent future illness.

- Do not conflate biology with "biomedicine": pharmacological interventions typically are based on reductionist models, but complex evolved biological systems are unlikely to respond in a simple "cause and effect" way (or in any one way) to any particular biomedical intervention.

- Challenge the ideology that science can render life "risk free" and that all risk can be quantified.

- Increase economic, professional, and structural incentives for physicians to have time to practice truly preventive medicine with their patients, to address social and economic obstacles hindering their ability to live healthy lives, and also to make complex medical decisions with their patients, including decisions regarding termination of treatment and acceptance of mortality.

- Encourage development of organisations and venues where experts and lay people can critically evaluate scientific evidence and obtain funding to: (a) research, explore, and scientifically test alternatives to the biomedical tendency to interpret embodied transitions, such as menopause, principally from the perspective of disease narratives, and (b) expose and provide education to counter manipulation of expert and lay opinion by sectors and people who benefit from sale of biomedical interventions (including pharmacological agents).

correctly, exercise, take preventive medication, and undergo regular screening tests-they will escape major health problems and premature death. By extension, those who fail to behave wisely and to follow the medical experts' advice will be punished by ill health and early death. The imperative to take "risk reducing" drugs is thus increased by its close fit with dominant ideologies that embrace, rather than challenge, moralistic individualism and disregard social determinants of disease.

Missing element number 5 : the gendering of hormones and regulation of women's sexuality

Finally, and perhaps most insidiously, the history of the development and promotion of HRT is inherently entangled with longstanding beliefs that sex hormones fundamentally 
explain women's and men's behaviour and biology, that women's "nature" and value derive from women's capacity to bear children, and that it is in "society's interest" to control women's reproductive systems. ${ }^{43}$ 137-144 Reflecting these beliefs, hormones that affect growth, development, and function of the reproductive system, as well as the course of pregnancy, became gendered and in the 1920s were termed "sex hormones" by the leading researchers of that era, who focused exclusively on their action on reproductive organs, tissues, and cells. ${ }^{43}{ }^{145}$ Hormonal manipulation of women's reproductive systems likewise was framed as a "natural" topic for scientific inquiry, far more so than analogous research on men's reproductive health. If, however, "sex hormones," had been conceptualised as one particular variety of hormones that affect cell proliferation, rather than as specialised molecules preoccupied with sex, then perhaps pharmacological change of women's hormone levels would not have been portrayed benignly as "hormone replacement therapy," but instead would have been more aptly seen as "hormone manipulation," with attendant implications for cell proliferation, including increased risk of cancer.

\section{CONCLUSION: ACCOUNTABILITY, COMPLEXITY, AND MORTALITY}

In closing, understanding HRT use in the 20th century-and influencing its use in the 21 st century-requires engaging not only with the science of HRT but also the social, political, and institutional context of this science. Far from a simple tale of scientific progress, or the value of randomised clinical trials over observational studies, the fundamental question we must confront is: why, for four decades, since the mid-1960s, were millions of women prescribed powerful pharmacological agents already shown, three decades earlier, to be carcinogenic? To answer this question, we must engage with core issues of accountability, complexity, and fear of mortality, and the conduct of socially responsible science (see box with recommendations for future scientific research and clinical practice). There are no short cuts.

\section{ACKNOWLEDGEMENTS}

Thanks to the Radcliffe Institute for Advanced Study, Cambridge, MA for funding and hosting the exploratory seminar (hormones, women, and cancer risk: professionals and activists facing "miracle molecules", 4-5 June 2004) that led to development of this article and also for including Dr Löwy as a Radcliffe Institute Fellow (20032004) for work related to this seminar's topic.

\section{Authors' affiliations}

N Krieger, Department of Society, Human Development and Health, Harvard School of Public Health, Boston, USA

I Löwy, J-P Gaudillière, Institute National de la Santé et de la Recherche Medicale, CERMES, Villejuif, France

R Aronowitz, History and Sociology of Science Department, and Family Practice and Community Medicine, University of Pennsylvania, Philadelphia, USA

J Bigby, Community Health Programs, Brigham and Women's Hospital, and Director, Harvard Medical School's Center of Excellence in Women's Health, Boston, USA

K Dickersin, The Center for Clinical Trials and Evidence-Based Healthcare, Brown University, Providence, USA

E Garner, Gynecologic Oncology, Brigham and Women's Hospital, and Dana Farber Cancer Center, Boston, USA

C Hinestrosa, National Breast Cancer Coalition, Washington, USA R Hubbard (Emerita), Department of Biology, Harvard University, Cambridge, USA

P A Johnson, Division of Women's Health, Brigham and Women's Hospital, and Connors Center for Women's Health and Gender Biology, Boston, USA

S A Missmer, Harvard School of Public Health and Harvard Medical School, Boston, USA

J Norsigian, Our Bodies Ourselves, Boston, USA
C Pearson, National Women's Health Network, Washington, USA C E Rosenberg, B G Rosenkrantz (Emerita), Department of the History of Science, Harvard University

L Rosenberg, Slone Epidemiology Center, Boston University, Boston, USA

B Seaman, Author

C Sonnenschein, A M Soto, Department of Anatomy and Cellular Biology, Tufts University School of Medicine, Boston, USA

J Thornton, Center for Ecology and Evolutionary Biology, University of Oregon, Eugene, USA

G Weisz, Social Studies of Medicine, McGill University, Montreal, Canada

Competing interests: none.

\section{REFERENCES}

1 Writing Group for the Women's Health Initiative Investigators. Risk and benefits of estrogen plus progestin in healthy postmenopausal women. Principal results from the women's health initiative randomised controlled trial. JAMA 2002;288:321-33.

2 Hulley S, Grady D, Bush T, et al. Randomised trial of estrogen plus progestin for secondary prevention of coronary heart disease in postmenopausal women. JAMA 1998;280:605-13.

3 Petitti DB. Hormone replacement therapy for prevention. More evidence, more pessimism. JAMA 2002;288:99-101.

4 Seaman B. The greatest experiment ever performed on women. New York: Hyperion Books, 2003.

5 Kolata G, Petersen M. Hormone replacement study a shock to the medical system. New York Times 2002;10 Jul.

6 Wilson RA, Wilson TA. The fate of nontreated postmenopausal woman: a plea for the maintenance of adequate estrogen from puberty to the grave. $J$ Am Geriatric Society 1963;11:347-61.

7 Rhoades FP. Minimizing the menopause. J Am Geriatric Society 1967;15:346-54.

8 McCrea FB. The politics of menopause: the discovery of a deficiency disease. Social Problems 1983;31:111-23.

9 Stampfer MJ, Colditz GA. Estrogen replacement therapy and coronary heart disease: a quantitative assessment of the epidemiologic evidence. (reprinted Int J Epidemiol 2004;33:445-53). Prev Med 1991;20:47-63.

10 Mendelsohn ME, Karas RH. Protective effects of estrogen on the cardiovascular system. N Engl J Med 1999;340:1801-11.

11 Barrett-Connor E, Stuenkal CA. Hormone replacement therapy (HRT)-risks and benefits. Int J Epidemiol 2001;30:423-36.

12 Ettinger B, Grady D, Tosteson, et al. Effect of the womens' health initiative on women's decision to discontinue postmenopausal hormone therapy. Obstet Gynecol 2003;102:1225-32.

13 Hersh AL, Stefanick ML, Stafford RS. National use of postmenopausal hormone therapy: Annual trends and response to recent evidence. JAMA 2004;291:47-53.

14 Buist DSM, Newton KM, Miglioretti DL, et al. Hormone therapy prescribing patterns in the United States. Obstet Gynecol 2004; 104:1042-50.

15 Majumdar SR, Almasi EA, Stafford R. Promotion and prescribing of hormone therapy after report of harm by the women's health initiative. JAMA 2004;292:1983-8.

16 Andre M. L'impact de WHI sur les femmes. Quotidien de Médecin 2003; 12:Dec.

17 Grodstein F, Clarkson TB, Manson JE. Understanding divergent data on posthormonal hormone therapy. New Engl J Med 2003;348:645-50.

18 Stampfer M. Commentary: Hormones and heart disease: do trials and observational studies address different questions? Int J Epidemiol 2004;33:454-5.

19 Vandenbroucke JP. Commentary: The HRT story: vindication of old epidemiological theory. Int J Epidemiol 2004;33:456-67.

20 Barrett-Connor E. Commentary: Observation versus intervention-what's different? Int J Epidemiol 2004;33:457-9.

21 Kuller LH. Commentary: Hazards of studying women: the oestrogen oesterogen/progesterone dilemma. Int J Epidemiol 2004;33:459-60.

22 Petitti DB. Commentary: Hormone replacement therapy and coronary heart disease: four lessons. Int J Epidemiol 2004;33:461-3.

23 Lawlor DA, Davey Smith G, Ebrahim S. The hormone replacement-coronary heart disease conundrum: is this the death of observational epidemiology? Int J Epidemiol 2004;33:464-7.

24 Krieger N. Postmenopausal hormone therapy. (Letter). New Engl J Med 2003;348:2363-4

25 Lacassagne A. Les rapports entre les hormones sexuelles et la formation du cancer. Ergebnisse in Hormon- und Vitaminforschung 1939;2:259-96.

26 Lacassagne A. Relationships of hormones and mammary adenocarcinoma in the mouse. Am J Cancer 1939;37:414-24.

27 Auchincloss C, Haagensen DC. Cancer of the breast possibly induced by estrogenic substances. JAMA 1940;114:1517-23.

28 Gaudillière JP. Hormones at risk: cancer and the medical uses of industriallyproduced sex steroids in Germany, 1930-1960. In: Schlicht T, Tröhler US, eds. Risk and safety in medical innovation. London: Routledge (in press).

29 Gusberg SB. Precursor of corpus carcinoma estrogens and adenomateus hyperplasia. Am J Obstet Gynecol 1947;54:905-7. 
30 Taylor HC. Endocrine factors in the origin of tumors of the uterus. In: Twombley GH, Pack GT, eds. Endocrinology of neoplastic diseases. Oxford: Oxford University Press, 1947:119-37.

31 Nathanson IT. The relationships of hormones to diseases of the breast. In: Twombley GH, Pack CT, eds. Endocrinology of neoplastic disease. Oxford: Oxford University Press, 1947:138-78.

32 Kaufmann C, Aurel-Müller H, Butenandt A, et al. Experimentelle Beiträge zur Bedeutung des Follikelshormons für die Carcinomentstehung. Zeitschrift für Krebsforschun 1949:56:482-542.

33 Weinstein EM. Estrogen use in postmenopausal women-cost, risks and benefits. New Engl J Med 1980;303:308-16.

34 Coronary Drug Project. The Coronary Drug Project. Initial findings leading to modification of its research protocol. JAMA 1970;214:1303-13.

35 Hoover R, Gray L, Cole P, et al. Menopausal estrogens and breast cancer New Engl J Med 1976;295:401-5.

36 Ross R, Paganini-Hill A, Gerkins V, et al. A case control study of menopausal estrogen theory and breast cancer. JAMA 1980;243:1635-9.

37 Notelovitz M. Estrogen replacement therapy: indications, contraindications, and agent selection. Am J Obstet Gynecol 1989;161:1832-41

38 Bell S. Changing ideas: the medicalisation of menopause. Soc Sci Med 1987;24:535-42.

39 Rosenberg L. Hormone replacement therapy: the need for reconsideration. Am J Public Health 1993:83:1670-3.

40 Posthuma WFM, Westerndorp RGJ, Vandenbroucke JP. Cardioprotective effect of hormone replacement therapy in postmenopausal women: is the evidence biased? BMJ 1994;308:1268-9.

41 Pfeffer N. The stork and the syringe. Cambridge: Cambridge University Press, 1993.

42 Oudshoorn N. United we stand: the pharmaceutical industry, laboratory and clinics in the development of sex hormones into scientific drugs, 1920-1940. Science, Technology Human Values 1993;18:5-24.

43 Oudshoorn N. Beyond the natural body: archeology of sex hormones. London: Routledge, 1994.

44 Hausman BL. Ovaries to Estrogen: Sex hormones and chemical femininity in the 20th century. J Med Humanities 1999;20:165-76.

45 Seaman B, Seaman G. Women and the crisis in sex hormones. New York: Bantam Books, 1977.

46 Klein R, Dumble $\sqcup$. Disempowering midlife women: the science and politics of hormone replacement therapy. Women's Studies International Forum 1994; 17:327-44.

47 Hunt K. A 'cure for all ills'? Constructions of the menopause and the chequered fortunes of hormone replacement therapy. In: Wilkinson S, Kitzinger $C$, eds. Women and health: feminist perspectives. London: Taylor and Francis, 1994:41-65

48 Worcester N, Whatley MH. The selling of HRT: Playing on the fear factor. Feminist Review 1992;41:1-26.

49 Kaufert PA, McKinlay SM. Estrogen-replacement therapy: the production of medical knowledge and the emergence of policy. In: Lewin E, Olsen V, eds. Women, health and healing, towards new perspectives. New York: Tavistock, 1985:113-38.

50 Pearson C, Fugh-Berman A, Allina A, et al, for the National Women's Health Network. The truth about hormone replacement therapy. Roseville, CA: Prima Publishing, 2002

51 Breast Cancer Action. http://www. bcaction.org (accessed 3 Dec 2004)

52 Wilson RA. Feminine forever. New York: Evans, 1966

53 Leysden B. The medicalization of menopause: from "feminine forever" to "healthy forever". In: Lykke N, Braidotti R, eds. Between monsters, godesses and cyborgs: feminist confrontations with science, medicine and cyberspace. London: Zed Books, 1996:173-92.

54 Haenszel W, McCrea Curnen MG. The first fifty years of the Connecticut Tumor Registry: reminiscences and prospects. Yale J Biol Med 1986;59:475-84.

55 McCrea FB, Markle GE. The estrogen replacement controversy in the USA and the UK. Different answers to the same question. Social Studies of Science 1984; 14:1-26.

56 Löwy I, Weisz G. French hormones: progestins and therapeutic variation in France. Social Studies and Medicine 2005;60:2609-22.

57 Angell M. The truth about the drug companies: how they deceive us and what to do about it. New York: Random House, 2004.

58 Abramson J. Overdosed America: the broken promise of American medicine. New York: HarperCollins, 2004.

59 Mann C. Women's Health research blossoms. Science 1995;269:766-70.

60 Watkins ES. On the pill: a social history of oral contraceptives, 1950-1970. Baltimore: The Johns Hopkins University Press, 1998.

61 Coney S. The menopause industry. Alameda, CA: Hunter House, 1994:60-80.

62 Kennedy DL, Baum C, Forbes MB. Noncontraceptive estrogens and progestins: use patterns over time. Obstet Gynecol 1985;65:441-6.

63 Palmlund I. The marketing of estrogens for menopausal and postmenopausal women. J Psychosomatic Obstet Gynecol 1997; 18:158-64.

64 Palmlund I. The social construction of menopause as risk. J Psychosomatic Obstet Gynecol 1997; 18:87-94.

65 Kaufert PA. Myth and menopause. Sociol Health Illness 1982:4:141-66.

66 Boston Women's Health Book Collective. Our bodies ourselves for the new century. New York: Simon and Schuster, 1998:688-96.

67 Houck JA. What do these women want? Feminist response to "Feminine Forever," 1963-1980. Bull Hist Med 2003;77:103-32.

68 Lane-Claypon JE. A further report on cancer of the breast, with special reference to its antecedent conditions. Reports on public health and medical subjects no 32. Ministry of Health. London: His Majesty's Stationery Office, 1926.
69 Wainwright JM. A comparison of conditions associated with breast cancer in Great Britain and America. Am J Cancer 1931;15:2610-45.

70 Kelsey JL, Bernstein L. Epidemiology and prevention of breast cancer. Annu Rev Public Health 1996;17:47-67.

71 Lawlor DA, Ebrahim S, Davey Smith G. Role of endogenous oestrogen in aetiology of coronary heart disease: analysis of age related trends in coronary heart disease and breast cancer in England and Wales and Japan. BMJ 2002;325:311-12.

72 Turnstall-Pedoe H. Myth and paradox of coronary risk and the menopause. Lancet 1998;351:1425-7.

73 LaCroix AZ, Newton KM, Leveille SG, et al. Healthy aging: a women's issue West J Med 1997;167:220-32.

74 Khaw KT. Healthy aging. BMJ 1997;315:1090-6.

75 The Coronary Drug Project Research Group. The coronary drug project Findings leading to discontinuation of the $2.5-\mathrm{mg}$ day estrogen group. JAMA 1973;226:652-7.

76 Smith DC, Prentice R, Thomson DJ, et al. Association of exogenous estrogen and endogenous carcinoma. N Engl J Med 1975;293:1164-7.

77 Ziel HI, Finkle WD. Increased risk of endometrial carcinoma among the users of conjugated estrogens. N Engl J Med 1975;293:1167-70.

78 Petitti DB, Perlman JA, Sidney S. Estrogens and mortality. N Engl J Med 1986;315:131-2.

79 McPherson K, Hemminki E. Synthesising licensing data to assess drug safety BMJ 2004;328:518-20.

80 Grady D, Rubin SM, Petitti DB, et al. Hormone therapy to prevent disease and prolong life in postmenopausal women. Ann Intern Med 1992;117:1016-36.

81 Lawlor DA, Davey Smith G, Ebrahim S. Socioeconomic position and hormone replacement therapy use: explaining the discrepancy in evidence from observational and randomized controlled trials. Am J Public Health 2004; $94: 2149-54$

82 Krieger $\mathbf{N}$. Theories for social epidemiology in the 21 st century: an ecosocial perspective. Int J Epidemiol 2001;30:668-77.

83 Krieger N, ed. Embodying inequality: epidemiologic perspectives Amityville, NY: Baywood Publishers, 2004.

84 Barrett-Connor E. Postmenopausal estrogen and prevention bias. Ann Intern Med 1991;115:455-6.

85 Hemminki E, Sihvo S. A review of postmenopausal hormone therapy recommendations: potential for selection bias. Obstet Gynecol 1993;82:1021-8.

86 Sturgeon SR, Schairer C, Brinton LA, et al. Evidence of a healthy estrogen user survivor effect. Epidemiology 1995;6:227-31.

87 Petitti DB. Coronary heart disease and estrogen replacement therapy. Can compliance bias explain the results of observational studies? Ann Epidemiol 1994:4:115-18.

88 Vandenbroucke JP. Postmenopausal oestrogen and cardioprotection. Lancet 1991;337:1482-3

89 Barkhem T, Nilsson S, Gustafsson JA. Molecular mechanisms, physiological consequences and pharmacological implications of estrogen receptor action. Am J Pharmacogenomics 2004;4:19-28.

90 McLachlan JA. Environmental signaling: what embryos and evolution teach us about endocrine disrupting chemicals. Endocr Rev 2001;22:319-41.

91 Soto AM, Sonnenschein C. The two faces of Janus: sex steroids as mediators of both cell proliferation and cell death. J Natl Cancer Inst 2001;93:1673-5.

92 Markey CM, Rubin BS, Soto AM, et al. Endocrine disruptors from Wingspread to environmental developmental biology. J Steroid Biochem Molec Biol 2003;83:235-44.

93 Markey CM, Soto AM, Sonnenschein C. Environmental disruptors of sex hormone action. In: Henry HL, Norman AW, eds. Encyclopedia of hormones. San Diego: Academic Press, 2003:523-33

94 Colborn T, Dumanoski D, Myers JP. Our stolen future. New York: Dutton, 1996.

95 Krimsky S. Hormonal chaos: the scientific and social origins of the environmental endocrine hypothesis. Baltimore, MD: Johns Hopkins University Press, 2000.

96 Guillette L. Endocrine disrupting contaminants: an evolutionary perspective. Philadelphia, PA: Francis and Taylor, 1997

97 National Research Council, Committee on Hormonally Active Agents in the Environment. Hormonally active agents in the environment. Washington, DC: National Academy Press, 1999.

98 Colborn T, Dumanoski D, Myers JP. Our stolen future. Widespread pollutants with endocrine-disrupting effects. http://ourstolenfuture.org/Basics/ chemlist.htm (accessed 16 Dec 2005).

99 Thornton JW, McCally M, Houlihan J. Biomonitoring of industrial pollutants: health and policy implications of the chemical body burden. Public Health Rep 2002;117:315-23

100 Egeland GM, Sweeney MH, Fingerhut MA, et al. Total serum testosterone and gonadotropins in workers exposed to dioxin. Am J Epidemiol 1994; 139:272-81.

101 Yu ML, Guo YL, Hsu CC, et al. Menstruation and reproduction in women with polychlorinated biphenyl (PCB) poisoning: long-term follow-up interviews of the women from the Taiwan Yucheng cohort. Int J Epidemiol 2000;29:672-7.

102 Koopman-Esseboom C, Morse DC, Weisglas-Kuperus N, et al. Effects of dioxins and polychlorinated biphenyls on thyroid hormone status of pregnant women and their infants. Pediatr Res 1994;36:468-73.

103 Patandin S, Lanting Cl, Mulder PG, et al. Effects of environmental exposure to polychlorinated biphenyls and dioxins on cognitive abilities in Dutch children at 42 months of age. J Pediatr 1999;134:33-41. 
104 Ulrich EM Caperell-Grant A, Jung SH, et al. Environmentally relevant xenoestrogen tissue concentrations correlated to biological responses in mice. Environ Health Perspect 2000;108:973-7.

105 DeVito MJ, Birnbaum LS, Farland WH, et al. Comparisons of estimated human body burdens of dioxinlike chemicals and TCDD body burdens in experimentally exposed animals. Environ Health Perspect 1995; 103:820-31

106 Gray LE, Ostby JS, Kelce WR. A dose-response analysis of the reproductive effects of a single gestational dose of 2,3,7,8-tetrachlorodibenzo-p-dioxin in male long Evans hooded rat offspring. Toxicol Appl Pharmacol 1997; 146:11-20.

107 Harrison H, Pearce F. AAAS atlas of population and the environment. Berkeley: University of California Press, 2001

108 Markey CM, Coombs MA, Sonnenschein C, et al. Mammalian development in a changing environment: exposure to endocrine disruptors reveals the developmental plasticity of steroid-hormone target organs. Evolution and Development 2003;5: 1-9.

109 Markey CM, Wadia PR, Rubin BS, et al. Long-term effects of fetal exposure to low doses of the xenoestrogen bisphenol- $A$ in the female mouse genital tract. Biology of Reproduction. doi: 10.1095/biolreprod. 104.036301.

110 Ekbom A, Trichopoulos D, Adami HO, et al. Evidence of prenatal influences on breast cancer risk. Lancet 1992;340:1015-18

111 Henderson IC. Risk factors for breast cancer development. Cancer 1993:71:2127-40.

112 Russo J, Hu YF, Yang X, et al. Developmental, cellular, and molecular basis of human breast cancer. J Natl Cancer Inst Monographs 2000;27:17-37.

113 Hunt PA, Koehler KE, Susiarjo M, et al. Bisphenol a exposure causes meiotic aneuploidy in the female mouse. Curr Biol 2003:13:546-53.

114 Kurebayashi H, Betsui H, Ohno Y. Disposition of a low dose of 14Cbisphenol $A$ in male rats and its main biliary excretion as BPA glucuronide. Toxicological Sciences 2003;73:17-25

115 Oberg M, Sjodin A, Casabona H, et al. Tissue distribution and half-lives of polychlorinated biphenyls and serum levels of 4 -hydroxy-2,3,3', $4^{\prime}, 5$ pentachlorobiphenyl. Toxicological Sciences 2002;70:171-82.

116 Thornton J. Chemicals policy and the precautionary principle: the case of endocrine disruption. In: Tickner J, ed. Precaution, environmental science, and preventive public policy. Washington, DC: Island Press, 2003:103-26.

117 Thornton JW. Pandora's poison: chlorine, health and a new environmental strategy. Cambridge, MA: MIT Press, 2000.

118 Krieger N, Northridge M, Gruskin S, et al. Assessing health impact assessment: multidisciplinary and international perspectives. J Epidemiol Community Health 2003:57:659-62.

119 Kriebel D, Tickner J. Reenergizing public health through precaution. Am J Public Health 2001;91:1351-5.

120 Tickner J, Raffenperger C, eds. Protecting public health and the environment implementing the precautionary principle. Washington, DC: Island Press, 1999.

121 Larson EB, Fihn SD, Kirk LM, et al. The future of general internal medicine. Report and recommendations from the Society of General Internal Medicine (SGIM) Task Force on the Domain of General Internal Medicine. J Gen Intern Med 2004; 19:69-77.

122 Ma J, Stafford RS, Cockburn JM, et al. A statistical analysis of the magnitude and composition of drug promotion in the United States in 1998. Clin Ther 2003;25:1503-7.

123 Aronowitz RA. Situating health risks. In: Rosenberg CE, Stevens R, Burns R, eds. American health care history and policy. New Brunswick, NJ: Rutgers University Press (in press).

124 Sackett DL. The arrogance of preventive medicine. Can Med Assoc J 2002; 167:363-4.

125 Notelovitz M. Estrogen replacement therapy: indications, contraindications, and agent selection. Am J Obstet Gynecol 1989;161:1832-41.

126 Anonymous. Guidelines for counseling postmenopausal women about preventive hormone therapy. American College of Physicians. Ann Intern Med 1992;117:1038-41.

127 AGS Clinical Practice Committee. Counseling postmenopausal women about preventive hormone therapy. J Am Geriatr Soc 1996:44:1120-2.

128 Nawaz H, Katz DL. American College of Preventive Medicine Practice Policy Statement. Perimenopausal and postmenopausal hormone replacement therapy. Am J Prev Med 1999;17:250-4.
129 National Insitutes of Health State-of-the-Science Conference Statement. Management of menopause-related symptoms. Draft statement: March 23, 2005, http://consensus.nih.gov/ta/025/ 025MenopausalSymptomsDRAFThtml.htm (accessed 3 Apr 2005).

130 Editors. HRT: what are women (and their doctors) to do? Lancet 2004;364:2069-70

131 Watkins E. "Doctor are you trying to kill me?" Ambivalences about the patients' package insert for estrogen. Bull Hist Med 2002;76:84-104.

132 US Food and Drug Administration. FDA updates hormone therapy information for post menopausal women. P04-18. http://www.fda.gov/ bbs/topics/NEWS/2004/NEW01022.html (accessed 3 Apr 2005)

133 Medicines and Healthcare products Regulatory Agency (MHRA) and the Committee on Safety of Medicines (CSM). Hormone replacement therapy (HRT): latest safety update (updated 3 Dec 2003). http:// medicines.mhra.gov.uk/ourwork/monitorsafequalmed/safetymessages/ hrtsafetyupdatedecember2003.pdf (accessed on 3 Apr 2005).

134 L'Agence française de sécurité sanitaire des produits de santé (Afssaps). Dossier de presse: Traitment hormonaux substitutifs de la menopause. 12 Mai 2004. http://agmed.sante.gouv.fr/pdf/10/ddpths.pdf (accessed on 3 Apr 2005).

135 Lock M, Gordon D, eds. Biomedicine examined. Dordrecht: Kluwer Academic, 1988.

136 Fee E, Krieger N. Understanding AIDS: historical interpretations and the limits of biomedical individualism. Am J Public Health 1993;83:1477-86.

137 Hubbard R. The politics of women's biology. New Brunswick, NJ: Rutgers University Press, 1990: 136-40.

138 Doyal L. What makes women sick: gender and the political economy of health. New Brunswick, NJ: Rutgers University Press, 1995.

139 Fee E, Krieger N, eds. Women's health, politics, and power: essays on sex/ gender, medicine, and public health. Amityville, NY: Baywood Publications, 1994.

140 Smith-Rosenberg C, Rosenberg C. The female animal: medical and biological views of woman and her role in nineteenth-century America. In: Leavitt JW, ed. Women and health in America: historical readings. Madison, WI: University of Wisconsin Press, 1984:12-27.

141 Gordon L. Woman's body, woman's right: a social history of birth control in America. Harmondsworth: Penguin Books, 1977.

142 Dreifus C, ed. Seizing our bodies: the politics of women's health. New York: Vintage Books, 1979.

143 Ruzek SB. The women health movement: feminist alternatives to medical control. New York: Prager, 1978.

144 Morgen S. Into our hands: women health movement in the US. London: Routledge, 2002.

145 Long-Hall D. Biology, sex hormones and sexism in the 1920s. In: Wartofsky M, Gould C, eds. Women and philosophy. New York: Putnam, 1975:81-95.

146 Kopera $\mathrm{H}$. The dawn of hormones replacement therapy. Maturitas $1991 ; 13: 187-8$

147 Ettinger B. Overview of estrogen replacement therapy: a historical perspective. Proc Soc Exp Biol Med 1998;217:5-7.

148 US Department of Health, Education and Welfare. DES task force summary report, DHEW publication no 79-1688 (NIH). Bethesda, MD: National Institutes of Health, 1978.

149 Apfel RJ, Fisher SM. To do no harm: DES and the dilemmas of modern medicine. New Haven: Yale University Press, 1984

150 Bell SE. The meaning of risk, choice, and responsibility for a DES daughter. In: Radcliff KS, ed. Healing technology: feminist perspectives. Ann Arbor: University of Michigan Press, 1989:245-61.

151 Kennedy DL, Baum C, Forbes MB. Noncontraceptive estrogens and progestins: use patterns over time. Obstet Gynecol 1985;65:441-6.

152 Wyssowsky DK, Golden L, Burke L. Use of menopausal estrogens and medroxyprogesterone in the United States. Obstet Gynecol 1995;85:6-10.

153 Lupton D. Constructing the menopausal body: discourses on hormone replacement therapy. Body and Society 1996;2:91-7.

154 Kaufert P, Lock M. Medicalization of women's third age. J Psychosomatic Obstet Gynecol 1997;18:81-6.

155 The Women Health Initiative Group. Design of the women health initiative clinical trial and observational study. Control Clin Trials 1998;19:61-109. 